\title{
The Fountain Of Blanduzia And Ovid By Vasile Alecsandri - A Hermeneutical Perspective
}

\author{
Monica Adriana IONESCU \\ University of Bucharest
}

I shall observe (explore) in this study the way in which the Latin antiquity is reflected in the playwrights of Vasile Alecsandri, more precisely, Blanduzia's Fountain and Ovid, the way in which Horace's work is reflected in the play Blanduzia's Fountain and Ovid's work in the play Ovidius. The approach of this work is a comparative one, by comparative understanding any literature study that transcends the boundaries of national literature (WELLEK). ${ }^{1}$

The method or the strategy adopted is a hermeneutical one. E.D. Hirsch righteously said that the act of understanding is virtually a genius conjecture (or a wrong one) and there are neither methods to teach us how to develop conjectures, nor rules to generate intuitions. ${ }^{2}$

In Antiquity, Hermes was the God of Communication, but also the

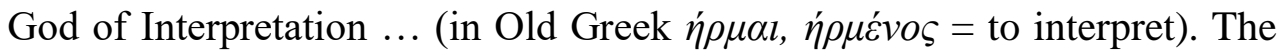
interpretation is an important stage of the act of criticism. The fundamental operations of the literary criticism can be classified into three stages: the pre-critical stage - it refers to the reaction to sensitivity or taste; the critical stage includes: the analysis, the interpretation, the explanation, the evaluation (issuing of a value judgment); the post-critical stage, which is structured into the following sub-stages: the characterization, the comparison, the classification, the hierarchization. In this process, the criticism takes as a starting point and at the same time as a type of approach: the method. In the Romanian literary criticism there have been used the following methods: the normative rhetoric method (Heliade- 


\section{The Fountain Of Blanduzia And Ovid}

Rădulescu), the normative aesthetics method (Maiorescu), the analytical explanation method (Gherea), the aesthetic analysis method (Lovinescu), the explanatory sociology method (the '50s), the aesthetic relativism method (the '60s), the analytical positivism method (the '70s), the aesthetic hermeneutic method (the ' 80 s up to the present).

Interpretations are aesthetic and extra-aesthetic. The aesthetic interpretation uses the form as a starting point (the aesthetic form of the work). The extra-aesthetic interpretation implies the existence of a number of philosophical, psychoanalytical, archetypal, psychological, sociological, etc. pre-concepts.

Modern literary hermeneutics cannot be based on a universal methodology of interpretation, as F. Schleirmacher considered, that a theory of interpretation had to lead to a methodology that should establish universal rules of understanding, applicable to all types of texts. However, there are some validity criteria for interpretation which, according to the researchers, are the following: relevance, pertinence, coherence, historicity and intertextuality. ${ }^{3}$

The criterion of relevance takes into account the fact that the exegetic grids cannot be used separately from the text.

The criterion of pertinence implies the fidelity towards the "keys" of the text, the submission to the text.

The criterion of coherence refers to the fact that interpretation should reveal all the components of the text in an appropriate way. "Appropriate" means the most probable and typical way in relation to the adopted interpretive strategy, based either on an external "grid" (sociological, psychological, etc.) or on a "grid" that is centred on the intention of the author.

The criterion of historicity brings forward the fact that no interpretation can disregard either the context of the reading or the context of the text enunciation (the original context).

The criterion of intertextuality takes into consideration that the work must be projected on the screen of interpretive tradition, the exegete 


\section{Monica Adriana IONESCU}

relating himself even implicitly to the previous interpretations (as far as there is a critical interpretive canon of the works). ${ }^{4}$

Alecsandri discovers Horace through his readings, both of them being part of the same spiritual family; there are spiritual affinities between Alecsandri and Horace:

He has comforted me, he has captivated me, he has helped me out of discouragement and has set me to work ... He is entitled to the first fruit of the year we have entered, so I have been writing for two uninterrupted months the ancient comedy The Fountain of Blanduzia. Horace is present in this work as a leading character. Have I managed to draw a resembling portrait? This literary success would be the accomplishment of my highest ambition as a poet. Several competent persons such as Maiorescu, my brother, Ion Ghica etc. have assured me that this dramatic work is the most perfect of my repertory. 5

Both endowed with temperament and classical spirit, impressing by their serenity and optimism (the joy of life) ... Like Horace, Alecsandri was a court poet "of wars, of patriotic praise, a national poet" 6 (Lovinescu), but also of frivolous, ephemeral love... both of them loving in a masculine, calm, thoughtful way, like true classics, with a sensual love...Elated spirits living an eternal present, but also refined Epicureans. Alecsandri could exclaim like Horace in the first book of the Odes (XILeuconoei):"Dum loquimur, fugerit invida / aetas: carpe diem, quam minimum credula postero." 7 The works The Fountain of Blanduzia and Ovid bring forward the drama of the man (poet) of genius, Alecsandri projecting himself "in two hypostases: that of an aged lover who, though a genius, has to sacrifice himself in favour of youth and that of a victim of mean jealousies". 8

Considered by G. Călinescu a melancholic comedy ${ }^{9}$ or by Al. Piru, a comedy of crepuscular love ${ }^{10}$, the work The Fountain of Blanduzia was written in 1883 and published in 1884 in the magazine "Literary discussions". The poet Horace, old, at the height of his glory, falls in love 


\section{The Fountain Of Blanduzia And Ovid}

with the young slave Getta. But she feels for the poet only a respectful admiration, while she loves the slave Gallus. There is a social conflict associated to the erotic conflict, Alecsandri reflecting here a reality of the ancient world: homines liberi et servi. The Fountain of Blanduzia is playing the part of a supra-character, as a meeting and parting place for the characters. It determines important actions, it relates to the main characters whose destiny it is setting up.

O fons Bandusiae splendidior uitro,/ dulci digne mero non sine floribus , /cras donaberis haedo ,/ cui frons turgida cornibus / (...) Fies nobilium tu quoque fontium / me dicente cauis impositam ilicem / saxis, unde loquaces / lymphae desiliunt tuae./(Liber tertius, Ode XIII) ${ }^{11}$

The Fountain of Blanduzia is the place where Gallus and Getta first meet; it is where Horace also sees Getta for the first time. This moment reminds us of Ode XXIII - Liber primus (of Horace), to which there can be drawn some fascinating parallels.

Vitas inuleo me similis, Chloe,/ quaerenti pauidam montibus auiis/ matrem non sine uano / aurarum et siluae metu. /(...) Atqui non ego te, tigris ut aspera / Gaetulusue leo, frangere persequor: ${ }^{12}$

It is by the fountain that Horace is parting from the couple (Getta and Gallus). Horace has the revelation of having been wrong, for an instant he is shaken by indignation and the desire to revenge, but instead he forgives the couple and, showing generosity and greatness, he sets them free. Getta had managed to find the lost manuscript of The Art of Poetry by the Fountain of Blanduzia. Horace chooses salvation through art. "Horaţiu O ! Carte, / Mă redeştepţi din visuri târzie şi deşarte ... / Din bunurile vieții cu tine mă aleg. / O ! Glorie, Horaţiu nu va pieri intreg." - Horace Oh! Book, / You wake me up from late and empty dreams ... / With you alone I am left from all the goods of life. / Oh! Glory, Horace shall not entirely die. ${ }^{13}$ Horace discovers the path to eternity, to immortality through poetic glory. "Non omnis moriar multaque pars mei / vitabit Libitinam" (Liber tertius, XXX - Epilogue). Death can be defeated through creation, through the work of art, since only the spirit is eternal ... 


\section{Monica Adriana IONESCU}

The second book, Ode XX, reveals to us the conscience of the poet's superiority and his uniqueness. The poet appears as a white bird floating in the sky, symbol of the high aspiration and the everlastingness of Horace's work.

Non usitata nec tenui ferar / penna biformis per liquidum aethera / uates neque in terris morabor / longius inuidiaque maior / urbis relinquam. / (...) ; Iam iam residunt cruribus asperae / pelles et album muto in alitem / superne nascunturque leves / per digitos umerosque plumae. I Iam Daedaleo notior Icaro / visam gementis litora Bosphori / Syrtes Gaetulas canorus / ales Hyperboreosque campos. ${ }^{14}$

If The Fountain of Blanduzia represents "the triumph of classicism

over romanticism in Alecsandri's literary work" 15 , the drama Ovid brings forward a rather romantic character. Alecsandri departs from the historical truth, growing apart from it, deforming it, creating a work of fiction. The drama was written and staged in 1885, rewritten at the end of 1886 and published posthumously. It is interesting to know that the poet- playwright finished the print corrections two days before his death (1890). It can be seen as a true literary testament. The poet of genius, Ovid, lusor tenerorum amorum, and the author of The Art of Love, passionately loved by Corinne, falls in love with Julia, the niece of the emperor Augustus. In the last act of the drama, the two characters (Julia and Ovid) remember the moment when they met each other ... The romantic nocturnal landscape, the starry sky, the moonlight ... The verse has an Eminescian sound, it is almost Eminescian ... Alecsandri is the creator of the Romanian poetic language and we are fully aware that without Alecsandri there wouldn't have existed an Eminescu ...

"Iulia / O, scumpe suvenire! / Era o noapte lină, cu cerul înstelat, / Duios îndemnătoare de vis îndelungat, / Febe, regina lumei, din faţa ei bălaie / Lăsa, zâmbind, să cadă o ploaie de văpaie / Pe undele mişcate alene de zefiri / Şi-n larg acoperite cu foi de trandafiri./ (...) Ovidiu / palpitând / Dar ... parcă te văd încă în barcă lunecând .../ Măreai cu-a ta 


\section{The Fountain Of Blanduzia And Ovid}

frumseţă al nopţei farmec bland .../ Mai spune ... Ah ! mai spune “ - Julia / Oh, sweet memory / It was a peaceful night, a starry sky / Inducing tenderly to long last dreams / Phoebe, all mighty queen, from her fairness / Is dropping, smiling, showers of fire / Over the waves that ripple in the breeze / And out at sea they are covered in petals of roses. / (...) Ovid / throbbing / But... it is as if I still discern you as the boat is sliding away / Your beauty enhanced the night's sweet magic .../ Say more ...Oh, please! Say more / 16

In Alecsandri's version, Ovid was exiled to Tomis, because of the bestial hatred of Ibis, Corinne's husband. Ibis informs the emperor about the love affair between Julia and Ovid. They recognize their fault before Augustus, who wished to marry Julia to the Dacian king Cotiso. Julia, after refusing to marry Cotiso, partakes in a party at Ovid's villa, together with the courtesans. In the following verses we meet again the Ovid of Amores and Ars amandi.

nunc iuvat in teneris dominae iacuisse lacertis; / si quando, lateri nunc bene iuncta meo est./ nunc etiam somni pingues et frigidus aer./ et liquidum tenui gutture cantat avis. (Amores, I, XIII)

"Ovid: Voi râdeţi ? Râsul vostru e râs de comedie. / Toti voi sunteţi ca mine: supuşi femeii, sclavi, / Dar faceţi ca fricoşii ce vreu să pară bravi, / Eu le iubesc pe toate, ş-aş vrea pe toate ele /Să le confund într-una, să fie toate-a mele ! / Pân-la sfârşitul lumei, lungind al vieţii fir, / Aş vrea, câte sor naşte, cu drag să le admir, / Căci eu iubesc în ele acea divinitate / Ce viaţa ne-o urzeşte cu zile încântate / Şi leagă faptul vieţii cu-apusul ei mâhnit / Prin lanţ în îflorire de-amor fără sfârşit." - Are you laughing? Yours is comedy laughter / You all resemble me: you are the woman's slaves, to her submitted / You just pretend like cowards who wish to pass for braves / I love them all, and all I'd like / To make them one, to make all mine! / Until the end of time, the thread of life prolonged / I wish I could admire all those who come to life / Cause I do love in them divinity / Which life is weaving with delightful days / And the life's wonder it connects to its sad end / By chains in its full bloom of endless love. ${ }^{17}$ 


\section{Monica Adriana IONESCU}

Ovid loves platonically, so he can love several beings at the same time, spotting in each of them equally that reverberation (reflection) of the Idea of Beauty.

Infuriated and, at the same time, grieved by Julia's behaviour, but also by her ignoring the threat of a harsh punishment, Augustus sends Ovid in exile, to Tomis.

The last act of the play evokes the winter landscape of Tomis.

"Sarmiza: Ce crivăț! Ce furtună ! Cum vâjâie prin horn! / Dava: Bătrâna iarnă albă mereu suflă din corn / De şapte nopţi şi zile, ca lupii din răstoace / În Tomis să s-adune pe gheaţă şi să joace / La nunta ei cu gerul. / O femeie: Au nun viscolul orb. / Alta: De frig în cuiburi crapă şi ouale de corb." - Sarmiza: Oh, what a wind, what a storm! How it is roaring down the chimney! / Dava: The old white winter is always blowing her horn / For seven days and seven nights, for wolves to gather from all over / To Tomis, to have a dance on ice / To join her wedding with the frost / A woman: Their guest is the blind snow./ Another: It is so freezing that the raven eggs are cracking in the nests. ${ }^{18}$

The poet Ovid, both in Tristia, and in Epistulae ex Ponto expresses his horror towards the winter of Dobrogea. He is terrified by the Crivitz wind, the frost, the frozen waters and, especially, the constant attacks of the barbarian populations.

Dum tamen aura tepet, medio defendimur Histro: /ille suis liquidis bella repellit aquis./At cum tristis hiems squalentia protulit ora, / terraque marmoreo est candida facta gelu, /dum prohibet Boreas et nix habitare sub Arcto, / tum patet has gentes axe tremente premi. / Nix iacet, et iactam ne sol pluuiaeque resoluant, /indurat Boreas perpetuamque facit / Ergo ubi delicuit nondum prior, altera uenit,/et solet in multis bima manere locis; (Tristia, liber III, X)

In the end of the drama, Ovid is forgiven by the emperor and Julia together with his other friends brings him the news that he has been 


\section{The Fountain Of Blanduzia And Ovid}

recalled to Rome. The poet dies feeling an inner reconciling and spiritual elevation, with the vision of a future Romania:

"Trec secoli...o! minune !...Aici în răsărit, / Vlăstarul , fiu al Romei, stejar a devenit, / Şi Istrul moşteneşte al Tibrului renume.../ Se nalţă-o nouă Romă, renaşte-o nouă lume./ Mormântu-mi se deschide...din el, în viitor, / Un lung torent de viaţă se-ntinde roditor./ Dumnezeiri ! ...Nu, ginta latină-n veci nu moare ! Ah! iată...noaptea...noaptea... ah ! mor!...ah !... / soare !... soare !..." - The centuries are passing by ... Oh! Wonder! ... Here at Levant, / The offspring, child of Rome, is now an oak, / The Istrus takes over the Tibre's fame.../ A new Rome is growing, a new world is born. / The grave lies open before me... and out of it, in what it is to come, / The stream of life is spreading wide and fertile. / Oh, Mighty God! ... No, the Roman race shall never die! / Oh! Here comes the night...the night...oh! Death has reached me! Oh! ... / Sun! ... Sun! ... ${ }^{19}$

In conclusion, I would like this study to become an invitation and also an inducement to the (re)reading and the (re)discovery of the literary works of the great classical authors Horace, Ovid, Alecsandri ...

\section{NOTES}

1 Wellek, René, Warren Austin, Teoria Literaturii, Bucharest, Pentru Literatură Universală Publishing House, 1967, p. 77.

2 E.D. Hirsch, Teoria dell'interpretazione e critica letteraria, Bolognia, 1973, pp. 210-213.

3 Paul Cornea, Introducere în teoria lecturii, Iaşi, Polirom Publishing House, 1998, p. 213.

${ }^{4}$ Ibidem, pp. 214-215.

5 Ion Pop, Dicţionar analitic de opere literare româneşti, Cluj-Napoca, Casa Cărţii de Ştiinţă Publishing House, 2000, p. 51.

6 Eugen Lovinescu, Critice, vol. III, Bucharest, Alcalay \& Co. Library Publishing House, 1920, p. 190. 


\section{Monica Adriana IONESCU}

7 Horatius, Opera Omnia, Bucharest, Univers Publishing House,1980, p. 91.

8 Dumitru Micu, Istoria Literaturii Române de la creaţia populară la postmodernism, Bucharest, Saeculum I.O. Publishing House, 2000, p. 104.

9 George Călinescu, Istoria literaturii române de la origini până în prezent, Bucharest, Minerva Publishing House, 1982, p. 316.

${ }^{10}$ Alexandru Piru, Surâzătorul Alecsandri, Bucharest, Minerva Publishing House, 1991, p. 199.

${ }^{11}$ Horatius, cited works, p. 215.

${ }^{12}$ Horatius, cited works, p. 111.

${ }^{13}$ Vasile Alecsandri, Despot vodă. Fântâna Blanduziei, Bucharest, Cartex Publishing House, 2000, p. 220.

14 Horatius, cited works pp. 177-179.

15 Şerban Cioculescu, Istoria Literaturii Române Moderne, Bucharest, Eminescu Publishing House, 1985, p. 91.

16 Vasile Alecsandri, Teatru, Bucharest, Tineretului Publishing House, 1968, pp. 478-479.

17 Vasile Alecsandri, Teatru, Bucharest, Tineretului Publishing House, 1968, p. 451.

18 Vasile Alecsandri, Teatru, Bucharest, Tineretului Publishing House, 1968, p. 460.

19 Vasile Alecsandri, Teatru, Bucharest, Tineretului Publishing House, 1968, pp. 482-483.

\section{BIBLIOGRAPHY}

Alecsandri, Vasile, Despot vodă. Fântâna Blanduziei, Bucharest, Cartex Publishing House, 2000

Alecsandri, Vasile, Teatru, Bucharest, Tineretului Publishing House, 1968

Călinescu, George, Istoria literaturii române de la origini până în prezent, Bucharest, Minerva Publishing House, 1982

Călinescu, George, Istoria Literaturii Române Compendiu, Bucharest Chişinău, Litera Internaţional Publishing House, 2001

Cioculescu, Şerban, Streinu, Vladimir, Vianu, Tudor, Istoria Literaturii Române Moderne, Bucharest, Eminescu Publishing House, 1985 


\section{The Fountain Of Blanduzia And Ovid}

Ciorănescu, Alexandru, Principii de literatură comparată, Bucharest, Cartea Românească Publishing House, 1997

Cornea, Paul, Interpretare şi raţionalitate, Iaşi, Polirom Publishing House, 2006

Cornea, Paul, Introducere în teoria lecturii, Iaşi, Polirom Publishing House, 1998

Drimba, Ovidiu, Ovidiu, Marele exilat de la Tomis, Bucharest, Saeculum I.O. Publishing House, 2001

Gadamer, Hans-Georg, Vérité et Méthode, Paris, Editions du Seuil, 1976

Grimal, Pierre, Literatura Latină, Bucharest, Teora Publishing House, 1997

Hirsch, E.D., Teoria dell'interpretazione e critica letteraria, Bolognia, 1973

Horatius, Opera Omnia, Bucharest, Univers Publishing House, 1980

Horatius, http://www.thelatinlibrary.com/

Hufnagel, Erwin, Introducere în hermeneutică, Bucharest, Univers Publishing House, 1981

Istoria Literaturii Române, Bucharest, Academiei Publishing House, 1968

Lovinescu, Eugen, Critice, vol. III, Bucharest, Alcalay \& Co. Library Publishing House, 1920

Micu, Dumitru, Istoria Literaturii Române de la creaţia populară la postmodernism, Bucharest, Saeculum I.O. Publishing House, 2000

Ovidius, Opere, Chişinău, Gunivas Publishing House, 2001

Ovidius, Scrisori din exil - Tristele - Ponticele, Bucharest, Mondero

Publishing House, 2000

Ovidius, http://www.thelatinlibrary.com/

Piru, Alexandru, Istoria Literaturii Române, Bucharest, Grai şi SufletCultura Naţională Publishing House, 2001

Piru, Alexandru, Surâzătorul Alecsandri, Bucharest, Minerva Publishing House, 1991

Pop, Ion, Dicţionar analitic de opere literare româneşti, Cluj-Napoca, Casa Cărţii de Ştiinţă Publishing House, 2000

Wellek, René, Warren Austin, Teoria Literaturii, Bucharest, Pentru Literatură Universală Publishing House, 1967 